\title{
The hiring and employment of older workers in Germany: A comparative perspective
}

\author{
John S. Heywood · Uwe Jirjahn
}

Published online: 10 December 2015

(C) The Author(s) 2016. This article is published with open access at Springerlink.com

\begin{abstract}
This paper focuses on the German labor market for older workers. It does so in comparison with other countries and with a unique focus on the role of employer incentives for retaining and hiring older workers. It argues that while employment of older German workers has improved due to changes in government policy, the labor market for older workers remains characterized by far less mobility and opportunity. While we recognize the potential explanations of reduced productivity and age discrimination, we review evidence pointing to the importance of life-cycle contracts (Hutchens, J Lab Econ, 4, 439-457, 1986; Lazear, J Polit Economy, 87, 1261-1284, 1979). These contracts can be efficient but typically imply that older workers will have difficulty being re-hired into career jobs after separation. We suggest that attempts to reduce or eliminate such life-cycle contracts are likely to be counterproductive but suggest how other countries, particularly Japan, have dealt with this issue.
\end{abstract}

Keywords Older workers · Deferred compensation Productivity - Discrimination - Labor market institutions

JEL Classification J14 $\cdot \mathrm{J} 33$

U. Jirjahn $(\square)$

University of Trier,

Trier, Germany

e-mail: jirjahn@uni-trier.de

J. S. Heywood

University of Wisconsin - Milwaukee,

Milwaukee, USA

e-mail: heywood@uwm.edu
Die Beschäftigung und Neueinstellung älterer Arbeitnehmer in Deutschland: Eine vergleichende Perspektive

Zusammenfassung Der vorliegende Beitrag gibt einen Überblick über den Arbeitsmarkt für ältere Arbeitnehmer in Deutschland. Der besondere Fokus liegt dabei auf einer international vergleichenden Perspektive sowie auf den Bedingungen, die die Entscheidungen von Arbeitgebern beeinflussen, ältere Arbeitnehmer zu beschäftigen und neu einzustellen. Ausgangspunkt der Überlegungen ist, dass Ältere, die arbeitslos werden, nach wie vor geringe Chancen haben, eine neue Stelle zu finden. Naheliegende Erklärungen könnten sein, dass dies mit einer geringeren Produktivität oder auch mit Diskriminierung zusammenhängt. Vorliegende empirische Studien liefern hier jedoch eher gemischte Ergebnisse. Eine alternative Erklärung besteht darin, dass vielmehr die Anreize, die Arbeitgeber einsetzen, um Mitarbeiter zur Leistungserbringungen $\mathrm{zu}$ motivieren, eine wichtige Rolle spielen. Ein Weg zur Motivation von Mitarbeitern ist der Einsatz von Formen zeitlich verzögerter Vergütung (Hutchens, J Lab Econ, 4, 439-457, 1986; Lazear, J Polit Economy, 87, 1261-1284, 1979). Zeitlich verzögerte Vergütung eignet sich jedoch nicht, neu eingestellte Arbeitnehmer zu motivieren, die nur über einen kürzeren erwarteten Beschäftigungshorizont verfügen. Daher präferieren Arbeitgeber, die dieses Motivationsinstrument nutzen, bei Neueinstellungen tendenziell eher jüngere und keine älteren Bewerber. Wir verweisen darauf, dass es jedoch als eher zweifelhaft erscheint, die Arbeitsmarktchancen Älterer dadurch verbessern $\mathrm{zu}$ wollen, indem man Arbeitgeber zur Abschaffung zeitlich verzögerter Vergütungsformen bewegt. So zeigt die japanische Erfahrung, dass sich die Arbeitsmarktchancen Älterer bei geeigneter Ausgestaltung 
auch im Fall einer intensiven Nutzung zeitlich verzögerter Entlohnung verbessern.

\section{Introduction}

Studies on older workers often focus on the incentives to retire. Typically the roles of working conditions, health problems and institutional factors (specifically early retirement possibilities) are considered (e.g., Coppola and Wilke 2014; Ebbinghaus and Hofaecker 2013; Roberts and Jones 2014; Schnalzenberger et al. 2014). However a deeper understanding of the labor market for older workers can only be obtained if we also take into account the personnel policy of firms and the resulting employment and hiring strategies.

In what follows, we highlight the labor market situation of older workers in Germany. We argue that while institutional reforms have improved their labor force participation, serious problems remain. The market is simply not dynamic and older workers once out of work are likely to remain so for a long time and may well exit not into employment but into retirement. Moreover, when they do re-enter to find jobs, they are often not able to get career jobs or full time jobs.

We follow this demonstration with a series of potential explanations for the limited employment opportunities for older workers. We first consider that older workers are poor hires because their productivity is substantially lower on average. We next consider that biases or poor information causes employers to simply discriminate against older job seekers. While we do not rule these out as partial explanations, we do suggest that the evidence is not overwhelming and that it seems unlikely these are complete explanations.

We highlight the importance of life-cycle motivational models which involve employers deferring compensation. These models imply tenure earnings slopes that are steeper than productivity increases as firms cause workers to post a quasi-bond that is repaid only later in tenure and dependent upon sufficient effort. In essence, the bond increases the cost of job loss and so creates effort incentives. The fact that workers are paid far more than their productivity late in their tenure makes mandatory retirement a frequent feature of deferred compensation. While this might create life-cycle efficiencies by increasing motivation, it creates difficulties for those older workers trying to re-enter employment. They cannot be motivated by life-cycle profiles and they cannot be paid the same as others with their experience receiving wages above productivity because of such profiles. The consequence seems often to simply not hire older workers or to relegate them to non-career and part time jobs.

We imagine potential policy responses both in the abstract, using Japan as an example, and within the constraints of
German institutions. We remain modestly pessimistic that substantial improvements can be achieved without harming the efficiencies associated with deferred compensation but try to outline possible avenues. We emphasize that the current use of deferred compensation is integrated into an interlocking set of German institutions that appear to add to productivity and this would be at risk if deferred compensation were reduced or eliminated.

\section{The labor market situation of older workers in Germany}

2.1 Increasing the labor force participation rate of older workers

Compared with workers in many other countries, those in Germany retain a generous pay-as-you-go public pension scheme with high effective replacement rates and relatively low retirement ages. Yet, recent reforms, while not unidirectional, have done much to change the incentives of older workers. These changes, together with increased labor market participation of women (Dietz and Walwei 2011), appear to have resulted in longer work lives and the better integration of older German workers (Dlugosz et al. 2013; OECD 2010).

As Germany faces a particularly large decline in its natural working-age population, improving the labor market integration of older workers has naturally become a priority. German fertility rates remain low and there is no expectation that they will increase substantially (Hoehn et al. 2008). Moreover, life expectancy has risen continuously and this trend is expected to continue at least over the next generation (Bonin 2009). As a consequence, BoerschSupan and Wilke (2006) show projections that the ratio of the population age 65 or older to the population 15-64 will rise to 0.43 by 2030 . Projections such as this, combined with early retirement ages and generous benefits led to a series of reforms designed to make the pension system more sustainable.

The age of retirement has been increased and will reach 67 by 2029 . The payouts have also been made more actuarially fair to reduce the incentive to retire early. Yet, discussion continues about steps that should be taken to reduce strategic behavior to circumvent early retirement penalties through disability. Moreover, very recent changes have moved the opposite direction with the ability for those who have 45 years of paying into the system to retire as early as 63. Despite the on-going changes and debates, it seems reasonable to conclude that the balance of the reforms is making a difference. Over the course of the decade the labor 
Fig. 1 LFPR by Age across Countries. (Source: OECD StatExtracts, "Labor Force Status by sex and Age," http://stats.oecd.org/ Index.aspx?DataSetCode=LFS SEXAGE_I_R)

\section{LFPR 2012 BY AGE AND COUNTRY}

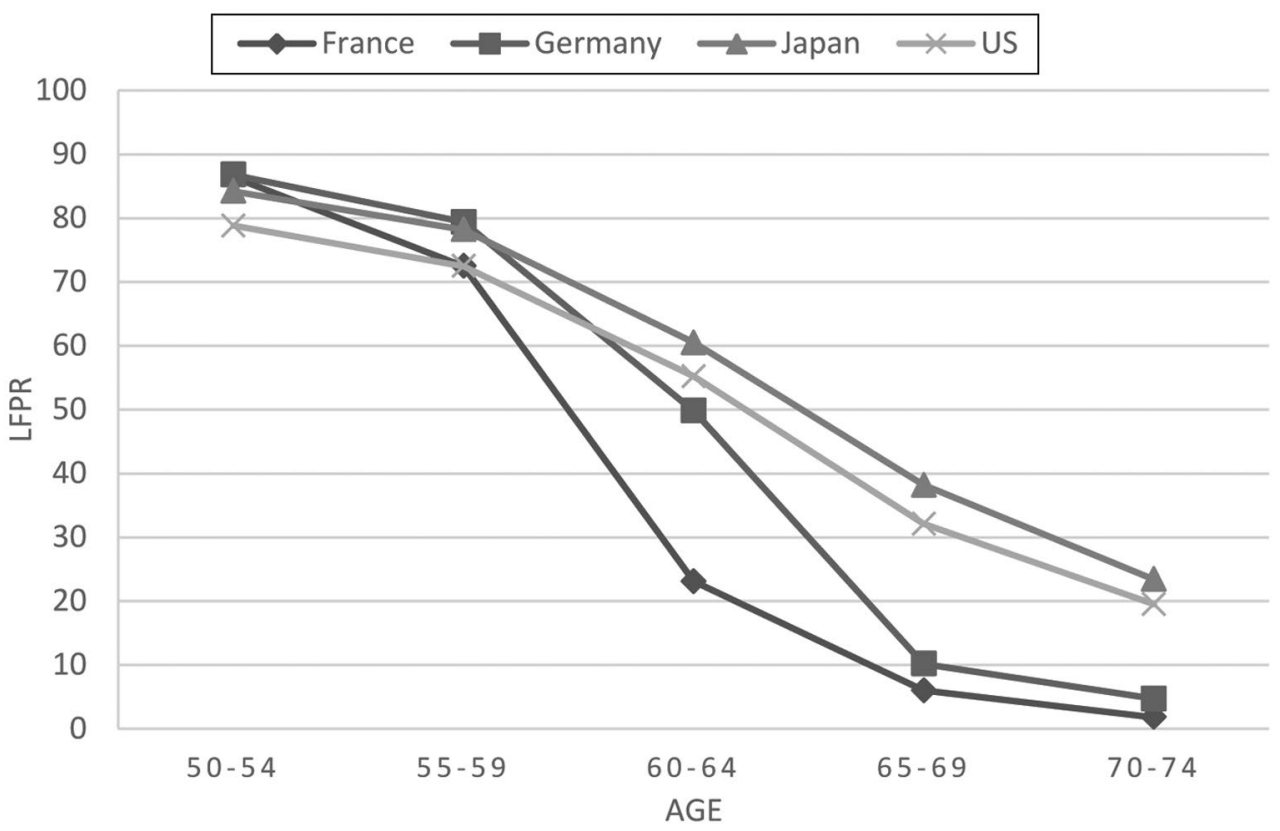

force participation rate of those between ages 55 and 64 has shown a strong and steady increase. ${ }^{1}$

\subsection{Has the labor market situation of older workers really improved?}

Even though the employment situation of older workers in Germany has improved, very substantial issues remain. First, while the labor market participation of older workers has increased, their labor market participation remains far below the employment ratios of other age groups. Moreover, it drops very quickly with advancing age. These points are illustrated in a comparison across four countries in Fig. 1. At age 55-59 the participation rate of Germany equals that of Japan and the US while being above that of France. With advancing age the German rate drops well below that of Japan and the US while approaching that of France. Making the same comparison for men shows that German participation rate exceeds that of the US in the youngest age cohort and then falls well below with advancing age (see Fig. 2). Limiting the comparison to women shows that both European countries actually start above Japan and the US but then drop substantially below as age increases (see Fig. 3). The drop for women is particularly interesting as until about the year of 2000, the LFPR for women aged 25-54 in the US was higher than in Germany but this has since reversed. Thus, while most women in Germany are more likely to par-

\footnotetext{
${ }^{1}$ Brenke and Zimmermann (2011) argue that rising educational levels of older workers have also contributed to their increase in the labor force participation.
}

ticipate than women in the US and Japan, this is not true of older women.

Second, positive developments must be qualified by the relatively intense use of partial retirement in Germany (Altersteilzeit). Most on partial retirement use the "block model" in which a period of full-time work is followed by a period of not working (Wanger 2009). This part-time work is somewhat misleadingly identified as employment both during periods when working and when not working. Thus, official statistics overestimate the number of older workers actually working at any point in time.

Third, and in many ways the most dramatic, unemployed older workers continue to face severe difficulties in finding a new job. The difficulties result in higher longterm unemployment for older workers in much of Europe (OECD 2010). This also holds for Germany. In 2012, 47\% of unemployed persons of the age group 55-64 were longterm unemployed compared to $36 \%$ across all age groups (Bundesagentur für Arbeit 2013). Unemployed persons age 55-64 who found a new job in 2012 had on average an unemployment duration of 56.1 weeks. This is nearly 20 weeks more than the average of 36.6 weeks across all age groups. Moreover, the higher unemployment substantially underestimates the difficulty as many older workers simply retire after an unsuccessful job search.

These additional difficulties in finding a new job become clear if one considers German labor market flows, the entries and exits from employment and, specifically, the transition from unemployment to employment for different age groups. The relative entry rate of older workers to employment compared to that of younger workers has simply not 
Fig. 2 LFPR by Age across Countries (Men). (Source: OECD StatExtracts, "Labor Force Status by sex and Age," http://stats.oecd.org/Index. asp $x$ ? DataSetCode $=$ LFS SEXAGE_I_R)
Fig. 3 LFPR by Age across Countries (Women). (Source: OECD StatExtracts, "Labor Force Status by sex and Age," http://stats.oecd.org/Index. aspx?DataSetCode $=$ LFS SEXAGE_I_R)

\section{LFPR (MEN) BY AGE 2012}

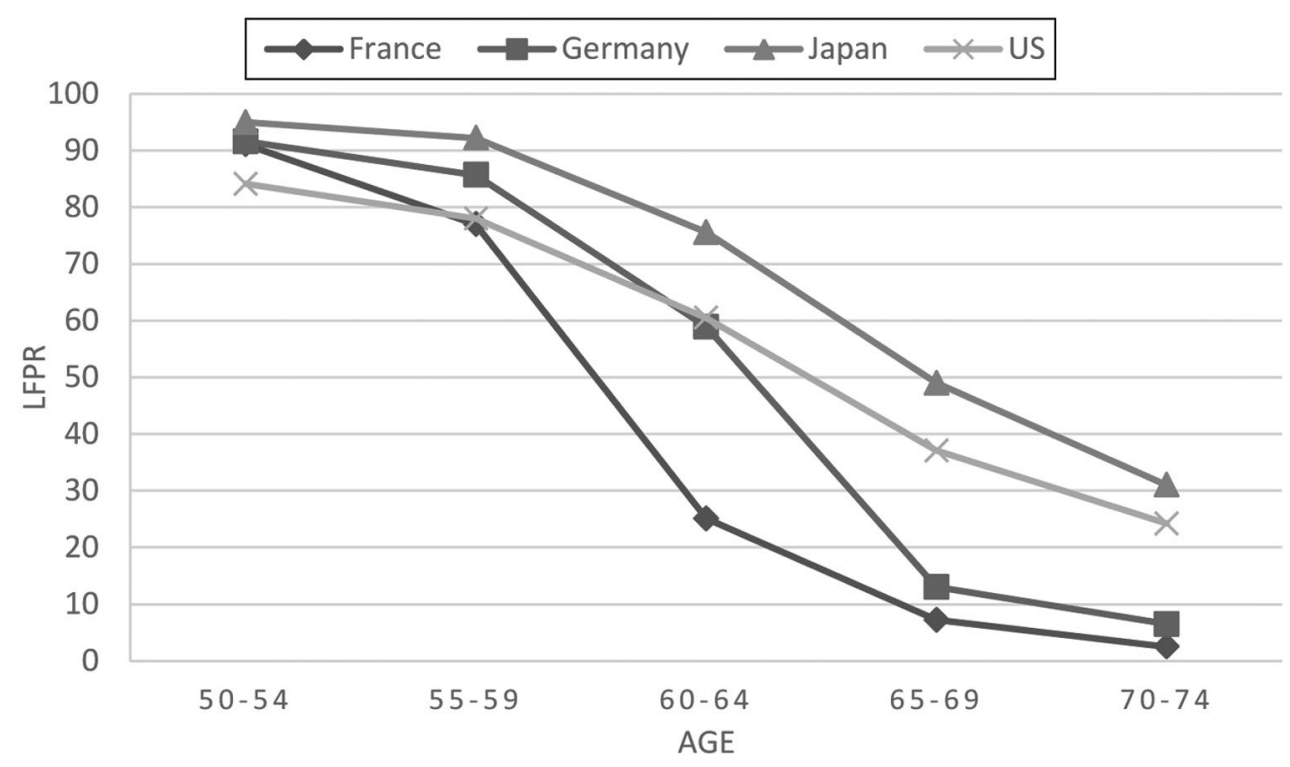

LPR (WOMEN) BY AGE 2012

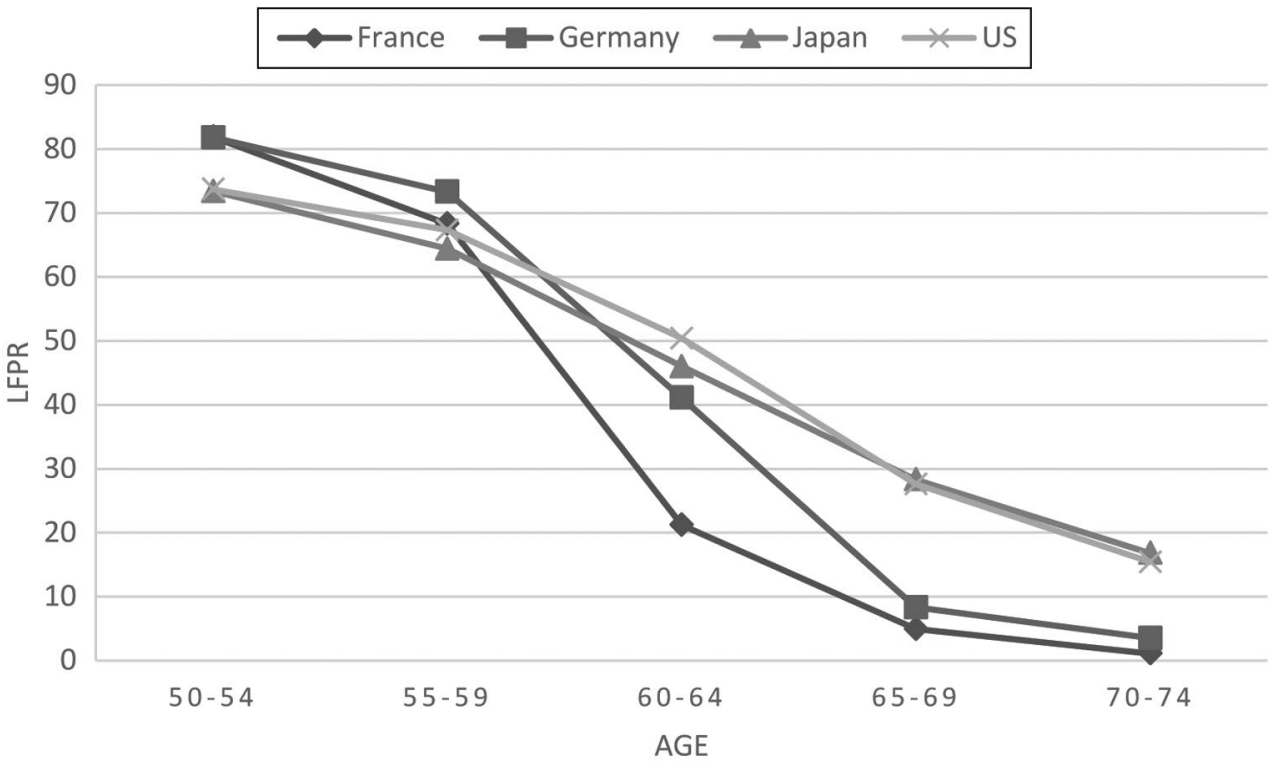

changed (Dietz and Walwei 2011). Table 1 highlights this point by showing that the entry rate of workers declines with age and, for example, those 55-59 have an entry rate only $1 / 3$ that of those less than 50 . Moreover, as the Table makes clear the entry rates for older workers (indeed, all workers) have been unchanged over the period from 2002 to 2010. Thus, the increased labor force participation seen for older workers comes exclusively from the employed exiting employment less frequently and simply retaining their jobs for longer. The re-employment probabilities for older workers have not improved. Thus, only $3.9 \%$ of the stock of older unemployed workers (age 50 or older) moved into unsubsidized employment in 2010 . This fell to only $2.1 \%$ for those 60 years of age or older (Dietz and Walwei 2011). Thus, one view of the recent reforms is that while they have improved the probability that firms retain older workers, they have not improved the probability that they hire older workers. The reasons behind this continued pattern will be a major focus of our review.

Adding to the difficulties, the earnings loss after nonemployment is larger for older workers. Examining German administrative data, Zwick (2012a) shows that while younger workers quickly catch-up to the earnings of those without a non-employment spell, many older workers never 
Table 1 German yearly job entries as a percent of age group employment

\begin{tabular}{lll}
\hline Age group & 2002 & 2010 \\
\hline $20-49$ & 30 & 30 \\
$50-54$ & 15 & 15 \\
$55-59$ & 12 & 12 \\
$60-64$ & 9 & 8 \\
\hline
\end{tabular}

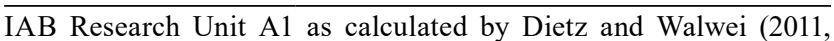
p. 369)

do. Older workers with a non-employment spell suffer a $10 \%$ earnings disadvantage 1 year after returning to work and a nontrivial earnings disadvantage remains even 6 years after returning to work.

Related to each of the last two points, many older German workers may be able to only find part-time work after a non-employment spell. While this may be the desired outcome for some workers, in the U.S. and U.K. a substantial portion of older workers report involuntary part-time status (Bell and Rutherford 2013; Reynolds and Wenger 2010). Among German employers, Heywood et al. (2011) present evidence that a sizeable proportion of those who would not hire older workers for full time jobs, indicate they will do so for part-time jobs. Thus, older workers seeking re-employment face diminished odds of finding work and when they do find work it provides lower wages and it may also provide fewer hours than they desire. In sum, it appears clear that, once separated, older workers have trouble reconnecting with career jobs. In what follows, we consider potential explanations for this pattern.

\section{Older workers and productivity}

\subsection{Age-productivity profiles}

One reason for the poor labor market opportunities of older workers could be that they simply have a lower productivity. Studies in occupational medicine, cognitive psychology and gerontology suggest that physical and some dimensions of mental fitness deteriorate from age 25 onwards (see Boersch-Supan et al. 2005; Skirbekk 2004; 2008; van Ours 2009 for surveys). Given this background, a series of econometric studies examine whether or not the age structure of the workforce has an influence on the productivity of firms. Using data from Taiwan, Liu et al. (2009) present evidence that firms with high shares of middle age workers are the most productive. This contrasts with evidence from Austria in which firms with young workers are the least productive but in which older age workers generate no decline (Mahlberg et al. 2013). This evidence is similar to that from France in which Aubert and Crepon (2007) show that workers less than age 40 contribute less to firm productivity but that there is no difference in contributions by age above 40 . Lal- lemand and Rycx (2009) present contrasting evidence from Belgium that firm productivity increases with the share of young workers (relative to middle aged) and decreases with the share of old workers (again relative to middle aged). Tipper (2012) presents evidence from New Zealand in which the age structure of workforce simply plays no role. In short, these studies provide no clear evidence on the relationship between workers' age and productivity.

This lack of clear evidence on the role of workforce age also holds true for Germany. Schneider (2007) examines age-productivity profiles for firms in the manufacturing and in the service sector. OLS regressions suggest an inverse $\mathrm{u}$-shaped profile in the manufacturing sector and a negative profile in the service sector. The age effects disappear completely in fixed effects estimates. Goebel and Zwick (2012) also find no significant age-productivity profiles once the endogeneity of the age structure of the workforce is taken into account by GMM estimates. Pfeifer and Wagner (2014a) obtain for manufacturing firms a positive concave age-productivity profile. Productivity increases until age 30 and does not significantly change afterwards. This result holds in both OLS and GMM estimates.

Such findings give rise to the question why the share of older workers has no clear negative effect on productivity despite the potentially lower physical and mental fitness of the aged. One explanation is that the lower fitness of older workers is offset by their greater experience. Boersch-Supan and Weiss (2007) support this view in their examination of the performance of work teams in a truck assembly plant of the German car manufacturer Daimler AG. While the quantity of output is determined by the speed of the assembly line, the quality of output depends on the production errors of a work team. Using average job tenure within a team as a proxy for experience, Boersch-Supan and Weiss examine age-productivity profiles with and without controlling for job tenure. If average job tenure is included in the regression, the share of older workers within a team is associated with increased production errors. This can be interpreted as a "pure age effect". By contrast, if average job tenure is not controlled for, the share of older workers is no longer associated with the production errors of a team. The share of older workers now captures not only the "pure age effect" but also an offsetting positive "experience effect."

\subsection{Age diversity}

Nonetheless the case study evidence of the truck assembly plant also shows that even if age per se has no influence on productivity, age diversity within the work teams can play a role. While the average age of workers within a team has no significant effect on production errors, age diversity of team members is associated with increased errors (BoerschSupan et al. 2006). Evidence from Belgium also suggests 
that age diversity is negatively associated with productivity (Garnero et al. 2014). This indicates that age diversity leads to more conflicts and communication difficulties within teams. To the extent that such results are general they would apparently argue for hiring a single cohort of workers and retaining them as they age.

However, the evidence on the productivity effects of age diversity is also mixed. Backes-Gellner et al. (2011) examine age-diverse workforces in German labor courts and find that a more diverse workforce results in higher organizational performance. They argue that an age-diverse workforce is better able to serve multiple performance dimensions. Ilmakunnas and Ilmakunnas (2011) also find a positive link between age diversity and productivity for Finland while Grund and Westergaard-Nielsen (2008) find a middle level of age dispersion leads to the highest productivity in Denmark.

\subsection{Are there moderating factors?}

The mixed results obtained by econometric studies indicate that there exists no easy uniform relationship between the age structure of the workforce and the productivity of a firm. The effect of the age structure may depend on circumstances and the type of firm. Goebel and Zwick (2013) obtain evidence that age-productivity profiles depend on specific human resource measures for older employees. They find that the relative productivity contribution of older workers is higher if firms provide specific equipment, create age-specific jobs or implement mixed-age working teams. Working time reductions and specific training do not appear to be associated with a higher productivity of older workers.

Moreover, the technology and innovativeness of a firm might play a moderating role as they influence skill requirements. There appears to be a wide held view among German managers that older workers are less flexible to cope with organizational and technological change (Koller and Gruber 2001). This view appears to be confirmed by a study by Schleife (2006). She finds that older workers are less likely to use computers. Relatedly, Pfeifer and Wagner (2014b) obtain the result that firms with a higher share of older workers employ a lower share of R\&D employees. However, from a theoretical viewpoint the link between older workers and technological change is not that clear. The experience of older workers may be valuable for a successful implementation of technological changes. Other studies for Germany do indeed provide little evidence that older workers harm technological change. Bertschek and Meyer (2009) find a positive relationship between IT intensity and productivity that is not affected by the proportion of older workers. Frosch et al. (2011) examine if staffing strategies characterized by rejuvenation of the workforce and increasing age diversity have an influence on the innovation success of firms. They do not obtain significant results. Backes-Gellner and Veen (2013) find that while age diversity in general is negatively associated with productivity, it has a positive interaction effect with innovativeness on productivity.

In the end it strikes us that the unsettled evidence on the role of worker age on firm productivity and the relatively small magnitudes of even those that find older workers detrimental are insufficient to generate the extremely difficult hiring situation that characterizes older workers. ${ }^{2}$ At a basic level, if older workers were slightly less productive, one would anticipate wage offers to adjust but not to see the widespread absence of hiring older workers. We now consider other alternatives.

\section{Discrimination}

Discrimination may be a critical reason for the poor labor market prospects of older workers. Buesch et al. (2009) provide a questionnaire study for Norway and Germany to examine if applicants with the same qualifications but with different ages are treated differently in notional hiring decisions. In the study, students and personnel managers received a description of an age neutral job and the CVs of hypothetical applicants. They had to fill in a questionnaire and to decide the applicant they would hire. The results of the study suggest that age discrimination plays a role in the hiring decisions in both countries with the age discrimination being more pronounced in Germany. An age differential of 14 years reduces the hiring probability of otherwise equal applicants by 22 percentage points in Germany and by 12 percentage points in Norway. The propensity to discriminate does not appear to differ between students and managers and does not depend on the age of the decision maker.

Correspondence studies in which pairs of fictitious applications are sent to actual employers are common in other countries. The applications submitted strive to be identical in all dimensions other than age. The critical issue is whether or not the employers are more likely to contact and pursue (seek an interview for example) the applications associated with the younger workers. Using such applications, Riach and Rich have confirmed statistically significant preferences by employers for younger workers in England (2010), France (2007) and Spain (2006). Such studies appear to have largely replaced earlier audit studies that used actual subjects (actors in essence) of different ages to pursue jobs (see Bendick et al. 1999). ${ }^{3}$

\footnotetext{
${ }^{2}$ We recognize that measurement problems and high levels of aggregation potentially limit studies on age structure and productivity. These limits are far less severe in studies such as Boersch-Supan and Weiss (2007) that use insider econometrics.

${ }^{3}$ See Riach and Rich (2002) for a review of the early field experiments on discrimination and Neumark (2010) for a methodology to improve the estimates that emerge from such audits and correspondence studies.
} 
It might be thought that laws against age discrimination would improve the hiring of older workers but there is little evidence in favor of this. Adams (2004) uses the state variation in anti-discrimination laws in the US to demonstrate that such laws increase employment among individuals in the protected age ranges. Yet, he finds employment declines among older workers above the age ranges protected by law. Most critically, the improved employment in the protected age ranges comes from a decrease in separation among these workers. They remain with their employer longer and are less likely to be fired or retire. Adams shows there is "simply no evidence" that older workers are more likely to be hired as a result of the legislation. Thus, the age discrimination laws seem to have improved the position of those employed but not helped those older workers seeking work. Viewed this way the laws may reinforce the tendency of employers to employ older workers but not hire them. Thus, it seems possible that the failure to hire older workers may reflect discrimination that is not eliminated by typical legal prohibitions. ${ }^{4}$

Discrimination can be either preference-based discrimination (Becker 1957) or statistical discrimination (Aigner and Cain 1977). Given that econometric studies have failed to provide clear evidence of a lower productivity of older workers, one might argue that statistical discrimination should play little or no role in the hiring of older workers. However, while older workers in general may be essentially as productive as younger workers, the variation in productivity levels may be higher for older than for younger workers (Heyma et al. 2014). This may make risk averse employers reluctant to hire older applicants. Moreover, even though older workers in general may have no productivity disadvantage, unemployed older workers who seek a job may remain on average less productive.

A theoretical model by Manger (2013) captures this latter idea. In the model, workers differ in their productivity, but individual productivity does not depend on age. Workers are matched to firms whereby the individual productivities of workers can only be observed after they have been hired. Firms fire unproductive workers and retain productive workers as long as possible. The probability that an imperfect matching process has sorted workers according to their productivity into the correct employment status increases with individual age. Thus, the older a productive worker, the higher the probability that he or she has already been matched to a good firm. Younger workers may be simply unemployed because they have not yet found a good

\footnotetext{
$\overline{{ }^{4} \text { Lahey (2008) }}$ presents evidence going even further. She contends that in states with aggressive enforcement of age discrimination laws, "firms seek to avoid litigation through means not intended by the legislation-by not employing older workers in the first place." She shows that the hiring of older workers becomes significantly less common in the face of strict enforcement of such laws.
}

job. However, those older workers who are unemployed are more likely to be unemployed because they are unproductive. As a consequence, there is a negative association between the age and the expected productivity of an unemployed worker. In this setting, firms have an incentive to statistically discriminate against older unemployed workers in the hiring decision.

Altogether, it seems plausible that some of the reluctance to hire older workers may be a combination of preference based discrimination and statistical discrimination as outlined above. Less clear is why such discrimination does not seem to permeate other aspects of the employment relation to the same extent. There is far less evidence that older workers are penalized in earnings or assignments within the firm. To the contrary the historic concern is that older workers have levels of pay that exceed their productivity. Thus, it has been three and half decades since Medoff and Abraham (1980) noted that pay often increases with age (tenure within the firm) even as productivity does not.

\section{Deferred compensation}

An alternative explanation, beyond productivity and discrimination, for the difficulties of older job seekers comes from the theory of delayed compensation. Under this theory the payment schemes designed to align incentives over a work life within firms may cause poor labor market prospects for older workers who apply for jobs. Even in the absence of productivity concerns and discrimination an employer may not be willing to hire older workers as the payment scheme does not motivate them. Both theoretical and empirical analyses have shown that deferred compensation can make an employer reluctant to hire older workers. At its most simple deferred compensation means that employers design compensation systems such that workers' wages are increasing in the tenure with their employer independent of worker productivity gains. Workers accumulate quasi-rents in the course of the employment relationship. These quasi rents are paid back late in their tenure with the employer. This pay back can come in the form of increasing tenure-wage profiles or employer-provided pensions that are clearly deferred due to vesting and the nature of defined benefit formulae (Lazear 1990).

\subsection{Theoretical background}

From a theoretical viewpoint, deferred compensation may result for two reasons. First, and more traditionally, firmspecific training plays a role (Hutchens 1988). Jobs entailing firm-specific training impose fixed costs to the firm that are minimized by hiring younger workers and thus hiring infrequently (Oi 1963). The consequence of specific train- 
ing is an upward-sloping earnings profile, reflecting that workers share both the cost of training and the later return on this investment (Becker 1964). Thus, firms offering specific training should have workers with longer tenure and provide reduced hiring opportunities for older workers.

Second, firms alleviate monitoring problems and improve incentives by using delayed compensation schemes (Lazear 1979, 1981). Hutchens $(1986,1988,1993)$ modeled a workplace in which fear of losing delayed compensation deters worker shirking, increases productivity and generates long-term employment relationships. In this view the firm does not hire older workers because their shorter employment horizon means they are less well motivated by delayed compensation. ${ }^{5}$

In the appendix, we present a simple theoretical illustration. A two-period efficiency wage model shows that an employer using deferred compensation prefers to hire younger workers. The employer can design two types of labor contracts. On the one hand, the employer can sign spot contracts with the workers each period. In this case, the employer pays the same efficiency wage in the first and in the second period to deter shirking. On the other hand, the employer can sign life cycle contracts with the workers, hire them in the first period and promise employment security for the two periods as long they are not caught shirking. The wage of the second period is the usual efficiency wage but, compared to the spot market contract, the employer can lower the first-period wage. Under the life cycle contract, the prospect of the second-period efficiency wage motivates workers to exert effort in the first period. Thus, the employer reduces labour costs by offering a life cycle contract. The incentive effect of the contract is greater if workers have a high probability of staying in the labor force in the second period. As this probability is higher for younger than for older workers, employers using life cycle contracts prefers to hire younger workers.

Building on Hutchen's (1986) idea that employers may have an incentive to renege on life cycle contracts, we also extend the model to allow for overlapping generations. The employer may break the contracts by dismissing the current workers in the second period and replacing them with new hires who receive the lower entry wages. ${ }^{6}$ If workers anticipate this kind of employer opportunism, life cycle contracts lose their motivational effect. Thus, the effectiveness of life cycle contracts depends on the employer's credibility that she is committed to the promise of employment security. Reputation concerns or worker representation may help

\footnotetext{
${ }^{5}$ Goldin (1986) makes a similar argument claiming that women are less well motivated by delayed compensation because of their lower expected tenure.

${ }^{6}$ See Gokhale et al. (1995), Idson and Valetta (1996), Petersen (1992) and Valetta (1999) for empirical studies on employer default on deferred payment agreements.
}

overcome the commitment problem. We will return to this issue when discussing policy implications in Sect. 6.

\subsection{International evidence}

Both theories have received substantial testing starting with studies for the United States. Hutchens (1986) computes an index of older employees' hiring opportunities for occupation and industry cells in the US. This hiring opportunity index correlates negatively with three indicators of deferred compensation, namely tenure, pension provision, and mandatory retirement. Scott et al. (1995) emphasize that health insurance in the US represents deferred compensation. They find that firms providing health insurance hire a smaller share of older workers. Hirsch et al. (2000) show that the hiring opportunities of US workers age 50 and older are reduced in occupations with steep wage profiles and pension benefits. $\mathrm{Hu}$ (2003) examines US individual data showing a negative relationship between training costs and the age at hire.

Evidence based on data from other countries largely matches that based on data from the US. Mazerolle and Singh (1999) use Canadian data to show that older workers hired after a plant closure are unlikely to have jobs with "career growth", a finding consistent with the role of deferred compensation within an internal labor market. Heywood et al. (1999) demonstrate that older workers in Hong Kong face reduced hiring opportunity when the firm provides a pension, has a well developed internal labor market and has high average tenure. This is combined with evidence that older workers are less likely to be hired when jobs require considerable skill investment. Daniel and Heywood (2007) use UK establishment data confirming that the hiring of older workers is reduced by pensions, steep wage profiles and internal labor markets and that longer training time also reduces the probability of hiring older workers. In addition, Adams and Heywood (2007) use Australian establishment data to confirm that steeper tenure-wage profiles reduce the age of new hires.

Taken together, the international studies show a remarkably consistent pattern of results. In each of the countries examined deferred compensation has the predicted influence on the employment and hiring of older workers. This gives rise to the questions of how prevalent deferred compensation is and of its effectiveness in motivating workers to provide effort. The answers to these questions are crucial as they yield further insights into the significance of deferred compensation for the labor market prospects of older workers.

Examining a large Chinese textile operation, Dong et al. (2007) test the extent of deferred compensation by contrasting the rate of increase in earnings with tenure and in worker 
productivity within a firm. ${ }^{7}$ They confirm tenure wage profiles that increase far faster than the growth in productivity. This joins similar confirmations that use performance data from a large Dutch manufacturer (Dohmen 2004) and a large Italian firm (Flabbi and Ichino 2001). In each case there is a return to tenure independent of worker productivity. In addition, Fukao et al. (2006) examine matched employer-employee data from Japan demonstrating far steeper wage-tenure profiles than productivity-tenure profiles, again supporting the role of deferred compensation. ${ }^{8}$

Another strand of research compares the tenure-earning profiles across groups of workers. The idea is that the profiles should be steeper in situations where imperfect monitoring and asymmetric information make the use of deferred compensation necessary to motivate workers. Lazear and Moore (1984) compare independent contractors (in business for themselves) and employees doing the same job. They argue that the extent of deferred compensation can be examined by this comparison because the employer has an incentive to rearrange the compensation for employees but that self-employment eliminates any reason to defer compensation. Indeed, the earnings profile of the employees emerges as much steeper supporting the presence of deferred compensation for the employees. Kotlikoff and Gohkale (1992) compare sales workers with more nearly verifiable productivity with their managers with less clearly verifiable productivity. The earnings profiles of the managers show greater deferred compensation with earnings below productivity early in career and above productivity late in their career. The earnings of sales workers essentially match their productivity over their career.

There are also studies examining the incentive effects of deferred compensation directly. These studies confirm that deferred compensation can be a powerful incentive device. Adams and Heywood (2011) show that self-reported effort is higher in both the US and Australia when tenure-wage profiles are steeper. Moreover, in keeping with life-cycle incentives, this finding is generated almost exclusively by younger workers reporting greater effort when facing a steeper profile.

\footnotetext{
${ }^{7}$ This harkens back to the original examination by Medoff and Abraham (1980) but the current authors have particularly good ("objective") measures of individual productivity.

${ }^{8}$ We note that studies that examine wage-age and productivity-age profiles instead of wage-tenure and productivity-tenure profiles provide rather mixed evidence. Cataldi et al. (2011) confirm deferred compensation in Belgium. They show that younger workers are paid below and older workers above their marginal productivity. Cardoso et al. (2011) find no evidence of deferred compensation for Portugal. The wages of younger workers increase in line with productivity while the wage increases lag behind productivity gains as prime-age approaches. Yet, age is only an incomplete proxy for tenure. Thus, it is more difficult to identify patterns of deferred compensation by examining agetenure and age-productivity profiles
}

Huck et al. (2011) design classroom experiments to contrast a situation in which firm players have the ability to credibly commit to deferred incentives with a treatment in which they do not have this ability. While in the former many firms make use of the incentives and it works to increase effort, in the latter there is a very dramatic loss in efficiency as such arrangements break down. This contrast demonstrates to the authors "the success of the Lazear model - the difference deferred compensation makes (p. 842)." Macpherson et al. (2014) compare deferred compensation with an efficiency wage in classroom experiments. While their experimental results find support for both models, the deferred compensation model is more cost effective (as predicted by theory).

\subsection{German evidence}

Germany provides a particularly interesting case study. Compared to the US, workers in Germany have longer job tenure (Farber 1998; Harhoff 1998). Moreover, upwardsloping earnings profiles appear to play an important role in Germany (OECD 2006; Zwick 2011). Furthermore, pensions voluntarily provided by the employers constitute one of the pillars (along with state pensions and individual savings) of the German retirement system (Schnabel and Wagner 1999). These employer provided pensions have been shown to reduce fluctuations in personnel (Rabe 2005; Schnabel and Wagner 2001) and to increase worker engagement (Bossler 2015). Finally, even though the age structure of the workforce may have little influence on productivity, a higher share of older workers appears to be associated with reduced profitability of German firms (Pfeifer and Wagner 2014a). Altogether, these facts suggest that deferred compensation plays an important role in the functioning of the labor market for older workers in Germany.

The German experience, indeed, conforms to the hypothesis that deferred compensation reduces the willingness to hire older workers. Heywood et al. (2010) examine the roles of employer provided pensions and employee share ownership in the employment and hiring of older workers in Germany. Employee share ownership is typically designed to create long-term employee involvement in the firm, to retain skilled employees, and to protect the firm's investment in firm-specific training. ${ }^{9}$ Employer provided pensions provide a particularly strong indicator of deferred compensation in Germany. Maximum vesting at the time of the data was either 10 or 12 years depending on the worker's age, far longer than in the U.S. (5 years) or the UK (2 years). Moreover, defined benefit plans, which typically grow faster later in tenure, dominate German pension provision. Thus, in

\footnotetext{
${ }^{9}$ See Robinson and Zhang (2005) for a detailed discussion on human capital investment and employee share ownership.
} 
Germany, most workers face real capital losses when leaving pension covered jobs before retirement. ${ }^{10}$ Such losses represent foregone quasi-rents associated with deferred compensation. Heywood et al. (2010) find that both employee share ownership and employer provided pensions are positive determinants of employing older workers and negative determinants of the willingness to hire older workers. Thus, firms retain older workers hired when they were younger but do not hire older workers. These findings fit the theoretical predictions. On the one hand, employers using deferred compensation employ older workers who entered the firm at a younger age in order to enable them to capture the quasi rents they have created by their efforts. On the other hand, those employers are less willing to hire older workers as older new hires are less motivated by deferred compensation.

Zwick (2012b) provides corroborating evidence. He uses linked employer-employee data from Germany to calculate firm-specific seniority wage profiles. His estimates suggest that firms with seniority wage profiles steeper than the sector average keep their employees longer but hire fewer older employees. Instead, these firms tend to hire employees with little experience.

Moreover, Heywood et al. (2011) show for Germany that even if firms with deferred compensation hire older workers, they are more likely to hire them only for peripheral jobs. Among the employers that are willing to hire older workers, those providing employee share ownership or pensions tend to hire older workers only for part-time jobs. Part-time jobs are a critical indicator of being out of the core internal labor market. Part-time employment more rapidly adjusts to demand changes than full-time employment. These more rapid adjustments are incompatible with the long expected tenure associated with deferred compensation. Moreover, skill requirements for part-time jobs are substantially lower than for full-time workers. Part-time jobs typically involve routine and repetitive tasks that require no long-term cooperation and facilitate direct monitoring so that the provision of incentives through deferred compensation may be not necessary (Hutchens 2001). Or put differently, firms with deferred compensation use this type of incentive scheme more likely for core jobs in the internal labor market but not for peripheral jobs. If they hire older workers, they only hire them for peripheral jobs as those jobs do not require deferred compensation to motivate workers.

Altogether, Heywood et al.'s (2011) findings imply that the disadvantage of older workers entailed by deferred compensation is underestimated if the type of employment is not taken into account. Deferred compensation not only decreases the probability that older workers are hired. It also decreases the probability that they are hired for jobs

\footnotetext{
${ }^{10}$ See Rabe (2005) for a detailed discussion on employer provided pensions in Germany.
}

with high quality when they are hired. Of course, some older workers may well desire part-time employment. They may see it as part of a phasing out of work. Nonetheless the basic point of Heywood et al.'s (2011) analysis is that deferred compensation may push older workers searching for employment also into involuntary part-time work. ${ }^{11}$

Finally, Pfeifer (2013) confirms that if older workers are hired, they are less likely to receive deferred compensation. His estimates suggest that wage-tenure profiles depend on the workers' entry age. Firms pay higher entry wages and flatter wage-tenure profiles to older entrants. This finding also fits the notion that employers prefer to motivate older hires through contemporaneous incentives as there is less room for deferred compensation.

In sum, the use of deferred compensation helps explain the less dynamic labor market for older workers (low job exit and job entry rates) and, in particular, the severe difficulties they face in finding a new job. This gives rise to the question what types of firms use deferred payment schemes such as employer provided pensions and seniority wages. Schnabel and Wagner (1999) find that larger firms, older firms and those with a high share of white-collar workers are more likely to provide pensions. The share of female employees is a negative determinant. Zwick (2011) estimates the determinants of rewarding seniority. He shows that export activities, firm size and the qualification of the workforce are positive determinants while high entry wages, the share of foreigners and the share of female employees are negative determinants. Industrial relations play also a role. We will return to that role below.

\section{Policy implications}

\subsection{Should the use of deferred compensation be discouraged?}

The finding that deferred compensation hurts the hiring prospects for older workers raises the issue of possible policy initiatives. One might argue that the use of deferred compensation should be discouraged in order to increase the chance that unemployed older people find a new job. However, whether this improves the labor market prospects of older people in general is not clear. While firms with deferred compensation are on the one hand much less willing to hire older workers, they employ on the other hand a higher share of older workers. Thus, a reduced use of deferred compensation may have a negative effect on the share of older workers employed by the firms.

\footnotetext{
${ }^{11}$ Farber (1999) shows for the U.S. that job losers are more likely to be hired into involuntary part-time jobs.
} 
In the end, the crucial question is whether stabilizing the employment of older people who have a job or creating new opportunities for older people who have no job will be more helpful in times of demographic change. Boersch-Supan (2003) argues that population aging will change the structure of demand for goods involving substantial reallocation of employment across different sectors and, hence, resulting in an increased mobility of labor. This may indicate that also the labor market for older workers must become more dynamic in the future so that policy should put more weight on improving the labor market prospects of older people who seek for new jobs.

Of course, one may question whether there is even need for policy intervention. Firms choose the incentive schemes that maximize the present value of their expected profits. If a firm does not use deferred compensation, it has to rely on contemporaneous incentives to motivate workers. For example, efficiency wages stand as an alternative to deferred compensation. Acemoglu and Newman (1997) show that providing incentives through deferred compensation can be less costly than providing contemporaneous incentives through efficiency wages (also see Macpherson et. al 2014). Thus, if a policy intervention induces firms to switch from deferred compensation to contemporaneous incentives, this may result in increased labor costs implying a negative effect on the level of employment in general.

\subsection{The role of institutional factors in Germany}

It is important to recognize that while market-driven forces are important, institutional frameworks also influence the use of deferred compensation. Specifically, industrial relations have been shown to influence the use of deferred compensation. Industrial relations in Germany are characterized by a dual structure of employee representation with both works councils and unions (Huebler and Jirjahn 2003). While works councils provide a highly developed mechanism for codetermination at the firm level, unions typically negotiate collective bargaining agreements with employers' associations on a broad industrial level. Zwick (2011) finds that the incidence of a works council in a firm and the coverage by a collective bargaining agreement increase the probability that the firm has a seniority wage profile steeper than the sector average.

At issue is whether the influence of industrial relations harms or improves economic welfare. On the one hand, one may argue that worker organizations foster internal labor markets over the course of their rent seeking activities (Addison and Siebert 1991). On the other hand, worker organization may help overcome market failures. Specifically, works councils may foster trust and cooperation within firms (Freeman and Lazear 1995; Smith 1991). This may be also important for a successful implementation of deferred compensation (Jirjahn 2009).

Deferred compensation presupposes that the employer promises employment security. Yet, the employer has an incentive to behave opportunistically and to dismiss workers late in their tenure in order to capture their quasi-rents (see the appendix for a simple theoretical illustration). A works council may ensure that promises made are also kept. A series of studies have shown that works councils are specifically effective in increasing firm performance when the firm is covered by collective bargaining (Jirjahn 2014). In this case, distributional conflicts are moderated outside the firm so that works councils can specialize in the creation rather than in the redistribution of rents. Against this background it is interesting that Heywood et al. (2010) and Zwick (2012c) show that a combination of works council incidence and collective bargaining coverage has a particularly strong influence on the use of deferred compensation. This indicates the influence of industrial relations on the use of deferred compensation is not primarily driven by rent seeking. It rather reflects the potential of industrial relations institutions to overcome market failures in the provision of appropriate incentives for workers.

Furthermore, one must take into account that the extensive system of apprenticeship training in Germany may contribute to the strong role of deferred compensation. Young people use the apprenticeship to enter internal labor markets that make further investment so firms can retain workers after training (Soskice 1994; Harhoff and Kane 1997). This binds workers and firms suggesting longer tenure and reduced hiring of older workers.

Industrial relations influence the system of apprenticeship training. Kriechel et al. (2014) show that firms with a works council make a higher net investment in training. These firms are also more likely to retain workers after training. The share of former apprentices still employed with the same firm after 5 years is significantly higher if a works council is present. Confirming previous research, the authors find that the effects of works councils are more pronounced for firms covered by collective bargaining agreements.

In conclusion, discouraging the use of deferred compensation would imply that institutions that now contribute to economic performance in Germany would need to be substantially changed. These changes could be counterproductive and would entail ambiguous employment effects. The crucial question whether or not these institutions will still work in times of demographic change.

\subsection{Learning from the Japanese experience}

One must recognize that the labor market implications of deferred compensation schemes depend on how they are 
actually incorporated into the general HRM and retirement policy of firms. Viewed in this way, the experience of Japan may be useful. Larger Japanese firms are known for their extremely steep tenure wage structure in which wages seemingly advance largely independent of variations in worker productivity growth (Fukao et al. 2006). This is combined with a strict and early mandatory retirement requirement (often at age 60) and extremely long job tenure at these same larger firms. These features are clearly recognizable from Lazear's (1979) description of deferred compensation and have caused many to view Japan as a leading example of its implementation (Hart and Kawasaki 1999). From what has been described, one would anticipate poor labor market dynamics for older workers with the associated difficulties in getting hired. Yet, the reality is rather different.

Figure 1 indicates that the labor force participation rate of older Japanese is much higher and that it does not drop off as steeply with age when compared to Germany. Heywood and Siebert (2009) suggest some of the reasons for the comparative Japanese success in retaining older workers. They argue that Japan has been highly successful in separating an initial labor market that uses internal labor markets and deferred compensation from a subsequent labor market that uses contemporaneous incentives and more nearly spot labor markets. This is facilitated by the common mandatory retirement age which is allowed because of the absence of US style age discrimination laws. Companies make large lump sum severance payments as employees leave at the end of their lifetime employment (typically at age 60). They then face the prospect of finding a new job but this is facilitated by employment protection laws that apply to regular work but not to temporary jobs (OECD 2004, p. 72). As a consequence, it is extremely common for workers to retire at age 60 but immediately sign a series of short-term temporary contracts with either their original employer or with others.

Individuals in Japan who work till 65 receive a state pension but this is paid irrespective of whether they are working or not. This also helps separate the two sequential labor markets and means that the pension does not affect retirement decisions. The consequence of this arrangement is that Japan has an extremely low implicit tax on continued work after age 65 . Duval (2003) shows it may be $10 \%$ or less and that it can be contrasted with, for example, France which has an implicit tax on continued worker of about $70 \%$. Thus, in Japan there are few disincentives for workers to continue in the labor market and few disincentives for firms to hire older workers.

As is always true in international comparisons, it is unclear whether specific elements of any country's employment relations system can be moved in parts over to another country. The set of interlocking institutions that to succeed in one country may not be able to be broken into parts are be successfully grafted into the institutions of another country.

\section{Conclusions}

We suggest that the continued lack of mobility and opportunity in the market of older workers reflects, in large part, the nature of life cycle contracts. Such contracts backload compensation to elicit loyalty, learning and effort from workers. While this may be efficient, it has as a consequence the tendency of firms to employ older workers but not hire them. The evidence of this seems clear both in Germany and in other countries. First, there is substantial evidence that such backloading of compensation exists. Second, it is nearly unanimous that in those circumstances with extensive backloaded compensation, older workers are less likely to be hired.

More research is needed on the types of jobs in which older workers are actually hired. Heywood et al. (2011) have suggested a share of German employers will only hire older workers for part-time jobs. Is that also true for temporary appointments? Can it also be confirmed that when hired for permanent jobs, older workers are less likely to be in career jobs with chances for significant advancement? Related to these questions are patterns of self-employment. The Japanese case is particularly interesting as workers frequently retire from an employer, ending a life time career as an employee, but continue to work for the same employer as a self-employed contractor. It would be interesting to identify how common such practices are in Germany.

While some of the answers to these additional research questions remain outstanding, the need to address German institutions and policies remains. We have argued that some of the institutions of the German labor market, works councils and apprenticeships in particular, interact with life-cycle contracting in a largely efficient fashion. Thus, attempts to discourage deferred compensation run the risk of generating substantial harms. Here again, the Japanese case remains intriguing as Japan also has significant deferred compensation that plays a critical role in motivation, learning and loyalty. The difference is the ease with which workers in Japan can terminate their career and continue to work, largely without implicit penalty, at their current firm. It may be worth exploring if German pension regulation and structure can be modified to further facilitate alternative types of employment by older workers after their formal retirement.

Against this background, future research should also examine if there is a link between the possibility of early retirement and the use of deferred compensation. While early retirement is often thought to reduce the labor force participation of older workers, it may provide flexibility for firms and workers to determine the optimal length of life 
cycle contracts. As industrial relations also influence the firms' use of early retirement programs (Bellmann and Janik 2010), it would be interesting to examine their specific role in the possible link between early retirement and deferred compensation.

Furthermore, we note that active labor market policy can play an important role in the hiring situation of older employees. Older job seekers often apply for the wrong jobs (Bellmann and Brussig 2007). Such mismatch may be reduced by job search assistance and intensified counseling (Boockmann and Brändle 2015). One dimension of improving job search would be to discourage older workers from applying for jobs with deferred compensation and to help older workers find jobs with contemporaneous incentives.

We recognize that the future of deferred compensation depends on changes in the nature of production. On the one hand, new technologies may entail improvements in the monitoring of worker performance. This could reduce the need to provide strong incentives through deferred compensation. On the other hand, there appears to be a reorganization of work toward more complex and multi-faceted jobs. This may make monitoring more difficult and, thus, requires an increased use of deferred compensation to motivate workers.

We also recognize that the future of deferred compensation depends on changes in industrial relations (Addison et al. 2013). For many years, the collective bargaining coverage and the prevalence of works councils have been decreasing. This may result in a declining use of deferred compensation.

Finally, we note that demographic change is likely to have implications for firms' future use of life-cycle contracts. An aging population may change the demand for goods resulting in an increased reallocation of jobs. This could make it more difficult for firms to provide life-cycle contracts to employees. As a consequence, the labor market for older workers may become more dynamic in the future. Furthermore, demographic change may imply that firms will face increased difficulties in filling their vacancies. These difficulties may be a particularly severe in Germany which faces a large decrease in its natural working-age population. This will have ambiguous consequences for the use of lifecycle contracts. On the one hand, firms may increasingly rely on those contracts to retain workers so that they have a smaller number of vacancies to fill. On the hand, firms may increasingly substitute contemporaneous incentives for lifecycle contracts and so fill their vacancies with older hires. We conclude then by recognizing that the implications of demographic change for the use of incentives and so for the hiring and employment policies of older workers stand as important future research.

\section{Executive summary}

Der vorliegende Beitrag gibt einen Überblick über den Arbeitsmarkt für ältere Arbeitnehmer in Deutschland. In einer international vergleichenden Perspektive werden insbesondere die Bedingungen analysiert, die einen Einfluss auf die Entscheidungen von Arbeitgebern ausüben, ältere Arbeitnehmer zu beschäftigen und neu einzustellen. Ausgangspunkt der Überlegungen ist, dass Ältere, die arbeitslos werden, nach wie vor geringe Chancen haben, eine neue Stelle zu finden. D. h., trotz einer erhöhten Erwerbsbeteiligung Älterer weist der Arbeitsmarkt für Ältere weiterhin eine sehr geringe Dynamik auf.

Eine naheliegende Erklärung könnte sein, dass dies mit einer geringeren Produktivität älterer Arbeitnehmer zusammenhängt. Vorliegende empirische Studien liefern hier jedoch ausgesprochen heterogene Ergebnisse. Ein weiterer Grund könnte darin bestehen, dass Ältere am Arbeitsmarkt diskriminiert werden. Hierfür gibt es durchaus Evidenz. Allerdings ist fraglich, ob sich die schlechteren Arbeitsmarktchancen älterer Arbeitsloser allein auf Diskriminierung zurückführen lassen.

Eine dritte Erklärung besagt, dass vielmehr die Anreize, die Arbeitgeber einsetzen, um Mitarbeiter zur Leistungserbringungen zu motivieren, eine wichtige Rolle spielen. Ein Weg zur Motivation von Mitarbeitern ist der Einsatz von Formen zeitlich verzögerter Vergütung wie z.B. Senioritätsentlohnung oder betriebliche Altersversorgung (Hutchens 1986; Lazear 1979). Zeitlich verzögerte Vergütung eignet sich jedoch nicht, neu eingestellte Arbeitnehmer zu motivieren, die nur über einen kürzeren erwarteten Beschäftigungshorizont verfügen. Daher präferieren Arbeitgeber, die dieses Motivationsinstrument nutzen, bei Neueinstellungen tendenziell eher jüngere und keine älteren Bewerber. Empirische Studien belegen nicht nur, dass zeitlich verzögerte Vergütungsformen in der Tat ein wichtiges Anreizinstrument darstellen. Sie zeigen zudem, dass dieses Anreizinstrument erhebliche Konsequenzen für die Arbeitsmarktchancen älterer Arbeitnehmer hat. Zwar beschäftigen Arbeitgeber mit zeitlich verzögerten Vergütungsformen einen höheren Anteil älterer Arbeitnehmer. Sie sind zugleich aber zurückhaltend bei der Neueinstellung Älterer. Bemerkenswert ist, dass es sich hierbei um einen sehr einheitlichen Befund handelt, der sich nicht nur für Deutschland, sondern auch für eine Reihe anderer Industriestaaten nachweisen lässt.

Wir verweisen darauf, dass es eher fraglich erscheint, die Arbeitsmarktchancen Älterer dadurch verbessern zu wollen, indem man Arbeitgeber zur Abschaffung zeitlich verzögerter Vergütungsformen bewegt. Bei zeitlich verzögerter Vergütung handelt es sich um ein sehr effektives Anreizinstrument, das sich für viele Arbeitgeber von Vorteil erweist. Gleichwohl können die Arbeitsmarktchancen Älterer auch 
bei intensiver Nutzung von zeitlich verzögerter Entlohnung durch eine geeignete Ausgestaltung verbessert werden. Dies zeigt insbesondere auch die japanische Erfahrung.

\section{Appendix: A Simple Theoretical Illustration}

\section{A.1 Deferred Compensation and Older Workers}

We model deferred compensation within an efficiency wage framework. Consider an employer living for two periods $(t=1,2)$ and requiring one worker each period. The pool of potential workers consists of older and younger workers. Let $q \in\left\{q^{\text {old }}, q^{\text {young }}\right\}$ denote the probability that a worker remains in the labor force in the second period: $0<\mathrm{q}^{\text {old }}<\mathrm{q}^{\text {young }}<1$ Workers have identical utility functions:

$$
u_{t}\left(w_{t}, e_{t}\right)=w_{t}-c e_{t},
$$

where $w_{t}$ is the wage in period $t, e_{t} \in\{0,1\}$ the effort in $t$, and $c e_{t}$ the disutility of effort, $c>0$. Each worker's alternative utility is $\bar{u}_{t}=\bar{u} \geq 0$ when in the labor force. When out of the labor force, utility is normalized to zero. Production requires that the worker exert effort $\left(e_{t}=1\right)$. However, effort cannot be perfectly monitored and if the worker shirks $\left(e_{t}=0\right)$, it is detected with probability $v_{t}=v, 0<v<1$.

The employer can design two types of labor contracts. One possibility is that the employer signs a spot contract with a worker each period. A spot contract lasts one period so that there are two spot contracts. The employer may sign two successive spot contracts with the same worker or she may hire different workers in the first and in the second period. Each spot contract pays $w_{t}^{s p o t}$ as long as the worker is not caught shirking. If the worker is caught shirking, the employer dismisses him without paying the wage and the worker receives the alternative utility $\bar{u}$. The employer sets the wage in such a way that the worker has no incentive to shirk. This is reflected by the no-shirking condition:

$$
w_{t}^{s p o t}-c=(1-v) w_{t}^{s p o t}+v \bar{u} .
$$

The utility from effort must be at least as high as the expected utility from shirking. Equation (2) implies that the spot wage is the same each period:

$$
w_{1}^{\text {spot }}=w_{2}^{\text {spot }}=\bar{u}+c / v .
$$

The second possibility is a life cycle contract with deferred compensation. The employer hires a worker in the first period and promises employment security for the two periods as long as the worker is not caught shirking. The life cycle contract specifies a wage $w_{1}^{\text {deferred }}$ for the first period and a wage $w_{2}^{\text {deferred }}$ for the second period. As the second period is the last period, the no-shirking condition is the same as in Eq. (2):

$$
w_{2}^{\text {deferred }}=w_{2}^{\text {spot }}=\bar{u}+c / v .
$$

When choosing effort in the first period, the worker recognizes that this decision also influences utility in the second period. The no-shirking condition of the first period is:

$$
\begin{aligned}
& w_{1}^{\text {deferred }}-c+q\left(w_{2}^{\text {deferred }}-c\right) \\
& =(1-v)-\left(w_{1}^{\text {deferred }}+q\left(w_{2}^{\text {deferred }}-c\right)\right)+v(1+q) \bar{u} .
\end{aligned}
$$

The left hand side shows the worker's expected utility if he exerts effort and consists of the current utility plus the expected utility of the second period. In the second period, the worker stays in the labor force with probability $q$. The right hand side is the expected utility if the worker shirks. With probability $1-v$ the worker is not detected and continues to work for the employer. With probability $v$ the worker is caught and loses the job for both periods receiving the alternative utility.

From (4) and (5), we obtain the first-period wage of the life cycle contract:

$$
w_{1}^{\text {deferred }}=\bar{u}+(1-q(1-v)) c / v .
$$

Thus, the worker's wage increases with tenure: $w_{1}^{\text {deferred }}<w_{2}^{\text {deferred }}$. Moreover, the first-period wage of the life cycle contract is smaller than the spot market wage: $w_{1}^{\text {deferred }}<w_{1}^{\text {spot }}$. The reason is that the life cycle contract is more effective in deterring shirking than the spot contract. If the worker is caught shirking in the first period, he loses both the current wage and the higher second period wage. The employer provides incentives at lower cost using deferred compensation.

Critical in our context, the first-period wage of the life cycle contract decreases in the probability that the worker remains in the labor force in the second period:

$$
d w_{1}^{\text {deferred }} / d q ?=-(1-v) c / v
$$

A higher probability of remaining means that the higher second-period wage is more effective in deterring the worker from shirking in the first period. Hence, the necessity to provide incentives through a high first-period wage decreases. Thus, as $q^{\text {young }}>q^{\text {old }}$, the first-period wage is lower for a younger than for an older worker. Taking into account that according to Eq. (4) the second-period wage is the same for both types of workers, this has two crucial implications. First, the wage-tenure profile is steeper for a younger worker than it would be for an older worker. Second, the 
employer has an incentive to hire the younger worker as the lower first-period wage implies lower overall costs.

\section{A.2 Deferred Compensation and the Employer's Commitment Problem}

We now assume $q=1$ and focus on the employer's commitment problem. The life cycle contract requires that the employer provides employment security but there exists an incentive to renege. The employer can save on the higher second-period wage by dismissing the current worker and hiring a new one at the low entry wage. When workers anticipate this, the incentive effects of the life cycle contract are weakened. To explore this we assume the employer lives infinitely and workers live for overlapping generations. Generation $I$ lives in periods 1 and 2, generation $I I$ in periods 2 and 3 , and so on.

First, as a benchmark, imagine that there is no commitment problem. In period 1 , the employer hires a worker from generation $I$ and offers a life cycle contract. Given $q=1$, the wages specified by the life cycle contract follow from Eqs. (6) and (4):

$$
\begin{gathered}
w_{1}^{\text {deferred }}=\bar{u}+c . \\
w_{2}^{\text {deferred }}=\bar{u}+c / v .
\end{gathered}
$$

In periods 3 and 4 , the employer hires a generation $I I I$ worker with the same contract. In periods 5 and 6 , a generation $V$ worker is hired and so on.

Now imagine the employer can renege on the promise of employment security with probability $z$. The employer fires the generation $I$ worker in period 2 and hires a generation II worker with a life cycle contract for the periods 2 and 3. This opportunism saves labor costs in the second period. With probability $1-z$ the employer cannot fire the generation $I$ worker and so hires a generation $I I I$ worker in the periods 3 and 4.

This employer opportunism weakens the incentive effect of the life cycle contract. If the generation $I$ worker anticipates the opportunism, $w_{1}^{\text {deferred }}$ and $w_{2}^{\text {deferred }}$ no longer induce effort in the first period implying an adjustment of the pay scheme. Denoting the adjusted wage by $\tilde{w}_{1}^{\text {deferred }}$, the no-shirking condition for the first period is:

$$
\begin{aligned}
& \tilde{w}_{1}^{\text {deferred }}-c+(1-z)\left(w_{2}^{\text {deferred }}-c\right)+z \bar{u}=(1-v) \\
& \left(\tilde{w}_{1}^{\text {deferred }}+(1-z)\left(w_{2}^{\text {deferred }}-c\right)+z \bar{u}\right)+2 v \bar{u} .
\end{aligned}
$$

From Eqs. (9) and (10), we obtain the first-period wage of a life cycle contract when there is the possibility of employer opportunism in the second period:

$$
\tilde{w}_{1}^{\text {deferred }}=\bar{u}+(1+z(1-v) / v) c
$$

This wage also holds for life cycle contracts offered to subsequent generations. Comparing Eqs. (8) and (11) it follows that the first-period wage is higher if there is the possibility of employer opportunism in the second period: $\tilde{w}_{1}^{\text {deferred }}>w_{1}^{\text {deferred }}$. Moreover, the first-period wage is increasing in the probability of employer opportunism:

$$
d \tilde{w}_{1}^{\text {deferred }} / d z=(1-v) c / v
$$

Thus, the higher the probability of employer opportunism the flatter is the tenure-wage profile. Or put differently, deferred compensation is more pronounced in situations with a low probability that the employer reneges on her promise of employment security.

Open Access This article is distributed under the terms of the Creative Commons Attribution License which permits any use, distribution, and reproduction in any medium, provided the original author(s) and the source are credited.

\section{References}

Acemoglu, D., Newman, A.F.: "The labour market and corporate structure," Centre for economic policy research, Discussion Paper No. 1708 (1997)

Adams, S.J.: Age discrimination legislation and the employment of older workers. Lab. Econ. 11, 219-241 (2004)

Adams, S.J., Heywood, J.S.: The age of hiring and deferred compensation: evidence from Australia. Econ. Rec. 83, 174-190 (2007)

Adams, S.J., Heywood, J.S.: Does deferred compensation increase worker effort? Manch. Sch. 79, 381-404 (2011)

Addison, J.T., Siebert, W.S.: Internal labour markets: causes and consequences. Oxford Rev. Econ. Pol. 7, 76-92 (1991)

Addison, J.T., Bryson, A., Teixeira, P., Pahnke, A., Bellmann, L.: The extent of collective bargaining and workplace representation: transitions between states and their determinants. A comparative analysis of Germany and Great Britain. Scot. J. Polit. Economy. 60, 182-209 (2013)

Aigner, D.J., Cain, G.G.: Statistical theories of discrimination in labor markets. Ind. Labor Relat. Rev. 30, 175-187 (1977)

Aubert, P., Crepon, B.: “Are Older Workers Less Productive?” CREST Working Paper, July (2007)

Backes-Gellner, U., Veen, S.: Positive effects of aging and age diversity in innovating companies-large-scale evidence on company productivity. Hum. Resour. Manag. J. 23, 279-295 (2013)

Backes-Gellner, U., Schneider, M., Veen, S.: Effect of workforce age on quantitative and qualitative organizational performance: conceptual framework and case study evidence. Organ. Stud. 32, 1103-1121 (2011)

Becker, G.S.: The Economics of Discrimination. University of Chicago Press, Chicago (1957)

Becker, G.S.: Human Capital. University of Chicago Press, Chicago (1964)

Bell, D.N.F., Rutherford, A.C.: 2013. "Older Workers and Working Time," IZA Discussion Paper, No. 7546 
Bellmann, L., Brussig, M.: "Recruitment and Job Applications of Older Jobseekers form the Establishments' Perspective," IZA Discussion Paper No. 2721, Bonn (2007)

Bellmann, L., Janik, F.: Betriebe und Frühverrentung: Angebote, die man nicht ablehnt. J. Labour Mark. Res. 42, 311-324 (2010)

Bendick, M., Brown, L., Wall, K.: No foot in the door: an experimental study of employment discrimination against older workers. J. Aging Soc. Policy. 10, 5-23 (1999)

Bertschek, I., Meyer, J.: Do older workers lower IT-enabled productivity? Firm-level evidence from Germany. Jahrbücher für Nationalökonomie und Statistik 229: 327-342 (2009)

Boersch-Supan, A.: Labor Market Effects of Population Aging. Labour. 17(Special Issue), 5-44 (2003)

Boersch-Supan, A., Weiss, M.: "Productivity and the Age Composition of Work Teams: Evidence from the Assembly Line," MEA Discussion Paper No. 148-2007 (2007)

Boersch-Supan, A., Wilke, C.: The German public pension system: how it will become an NDC system look-alike. In: Holtzmann, R., Palmer, E. (eds.), Pension Reform: Issues and Prospects for NonFinancial Defined Contribution (NDC) Schemes. World Bank, Washington DC (2006)

Boersch-Supan, A., Duezguen, I., Weiss, M.: 2005. "Altern und Produktivität: Zum Stand der Forschung," MEA Discussion Paper 73-05

Boersch-Supan, A., Duezguen, I., Weiss, M.: Altern und Produktivität - Eine neue Sichtweise der Arbeitsproduktivität. Personalführung 7, 74-81 (2006)

Bonin, H.: 2009. "15 Years of Pension Reform in Germany: Old Successes and New Threats," IZA Policy paper No. 11, July

Boockmann, B., Brändle, T.: “Coaching, Counseling, Case-Working: Do They Help the Older Unemployed Out of Benefit Receipt and Back into the Labor Market?" IZA Discussion Paper No. 8811, Bonn (2015)

Bossler, M.: "The Efficiency Wage Effect of Employer Provided Occupational Pensions," IZA Journal of European Labor Studies, Forthcoming (2015)

Brenke, K., Zimmermann, K.F.: “Ältere auf dem Arbeitsmarkt,” IZA Standpunkte No. 43, Bonn (2011)

Buesch, V., Dahl, S., Dittrich, D.: An empirical study of age discrimination in Norway and Germany. Appl. Econ. 41, 633-651 (2009)

Bundesagentur für Arbeit. "Ältere am Arbeitsmarkt-Aktuelle Entwicklungen," Arbeitsmarktberichterstattung: Der Arbeitsmarkt in Deutschland, September 2013, Nuremberg (2013)

Cardoso, A.R., Guimaraes, P., Varejao, J.: Are older workers worthy of their pay? An empirical investigation of age-productivity and agewage nexuses. De Economist. 159, 95-111 (2011)

Cataldi, A., Kampelmann, S., Rycx, F.: Productivity-wage gaps among age groups: does the ICT environment matter? De Economist. 159, 193-221 (2011)

Coppola, M., Wilke, C.B.: At what age do you expect to retire? Retirement expectations and increases in the statutory retirement age. Fisc. Stud. 35, 165-188 (2014)

Daniel, K., Heywood, J.S.: The determinants of hiring older workers: UK evidence. Lab. Econ. 14, 237-257 (2007)

Dietz, M., Walwei, U.: Germany-no country for old workers? J. Labour Mark. Res. 44, 363-376 (2011)

Dlugosz, S., Stephan, G., Wilke, R.A.: Fixing the leak: unemployment incidence before and after a major reform of unemployment benefits in Germany. Ger. Econ. Rev. 15, 329-352 (2013)

Dohmen, T.J.: Performance, seniority and wages: formal salary systems and indivdiual earnings profiles. Lab. Econ. 11, 741-763 (2004)

Dong, X.Y., Jones, D.C., Kato, T.: 2007. "Earnings-Tenure Profiles: Tests of Agency and Human Capital Theories using Individual Performance Data," IZA Discussion Paper No. 3122, October
Duval, R.: 2003. "The Retirement Effects of Old-Age Pension and Early Retirement Schemes in OECD Countries," OECD Economics Department Working Papers, No. 370

Ebbinghaus, B., Hofaecker, D.: "Reversing early retirement in advanced welfare economies: a paradigm shift to overcome push and pull factors. Comp. Popul. Stud. 38, 807-840 (2013)

Farber, H.S.: "Trends in Long-Term Employment in the United States, 1979-96," in Labor Markets in the USA and Germany: Third Public GAAC Symposium, pp. 251-284. Bonn: German-American Academic Council (1998)

Farber, H.S.: 1999. Alternative and part-time employment arrangements as a response to job loss. J. Labor Econ. 19, 149-169 (1999)

Flabbi, L., Ichino, A.: Productivity, seniority and wages: new evidence from personnel data. Lab. Econ. 9, 359-387 (2001)

Freeman, R., Lazear, E.: An economic analysis of works councils. In: Rogers, J., Streeck, W. (eds.) Works Councils - Consultation, Representation and Cooperation, pp. 27-52. University of Chicago Press, Chicago (1995)

Frosch, K., Goebel, C., Zwick, T.: Separating wheat and chaff: agespecific staffing strategies and innovative performance at the firm level. J. Labour Mark. Res. 44, 321-338 (2011)

Fukao, K.R., Kambayashi, D., Kawaguchi, H.U., Kwon, Y.G.K., Yokoyama, I.: 2006. "Deferred Compensation: Evidence from Employer-Employee Matched Data from Japan," Discussion Paper No. 187, Institute of Economic Research, Hitotsubashi University

Garnero, A., Kampelmann, S., Rycx, F.: The heterogeneous effects of workforce diversity on productivity, wages, and profits. Ind. Relat. 53, 430-477 (2014)

Goebel, C., Zwick, T.: Age and productivity: sector differences. De Economist. 160, 35-57 (2012)

Goebel, C., Zwick, T.: Are personnel measures effective in increasing productivity of old workers? Lab. Econ. 22, 80-93 (2013)

Gokhale, J., Groshen, E.L., Neumark, D.: Do hostile takeovers reduce extramarginal wage payments? Rev. Econ. Statist. 77, 470-485 (1995)

Goldin, C.: Monitoring costs and segregation by sex: a historical analysis. J. Lab. Econ. 4, 1-27 (1986)

Grund, C., Westergaard-Nielsen, N.: Age structure of the workforce and firm performance. Int. J. Manpower. 29, 410-422 (2008)

Harhoff, D.: "Comments on 'Trends in Long-Term Employment in the United States, 1979-96," " in Labor Markets in the USA and Germany: Third Public GAAC Symposium. Bonn: German-American Academic Council: 288-295 (1998)

Harhoff, D., Kane, T.J.: Is the German apprenticeship system a panacea for the U.S. labor market? J. Popul. Econ. 10, 171-196 (1997)

Hart, R.A., Kawasaki, S.: Work and pay in Japan. Cambridge University Press, Cambridge (1999)

Heyma, A., van der Werff, S., Nauta, A., van Sloten, G.: What makes older job-seekers attractive to employers. De Economist. 162, 397-414 (2014)

Heywood, J.S., Siebert, W.S.: 2009. "Understanding the Labour Market for Older Workers: A Survey,” IZA Discussion Paper No. 4033, Bonn

Heywood, J.S., Ho, L.S., Wei, X.: The determinants of hiring older workers: evidence from Hong Kong. Ind. Labor Relat. Rev. 52, 444-459 (1999)

Heywood, J.S., Jirjahn, U., Tsertsvadze, G.: Hiring older workers and employing older workers: German evidence. J. Popul. Econ. 23, 595-615 (2010)

Heywood, J.S., Jirjahn, U., Tsertsvadze, G.: Part-Time Work And The Hiring Of Older Workers. Appl. Econ. 43, 4239-4255 (2011)

Hirsch, B.T., Macpherson, D.A., Hardy, M.A.: Occupational age structure and access for older workers. Ind. Labor Relat. Rev. 53, $401-418$ (2000) 
Hoehn, C., Mai R., Michael F.: Demographic change in Germany. In: Hamm, I., Seitz H., Werding M. (eds) Demographic Change in Germany: The Economic and Fiscal Consequences. Springer, New York (2008)

Hu, L.: The hiring decision and compensation structures of large firms. Ind. Labor Relat. Rev. 56, 663-681 (2003)

Huck, S., Seltzer, A.J., Wallace, B.: Deferred compensation in multiperiod labor contracts: an experimental test of Lazear's model. Amer. Econ. Rev. 101, 819-843 (2011)

Huebler, O., Jirjahn, U.: Works councils and collective bargaining in Germany: the impact on productivity and wages. Scot. J. Polit. Economy. 50, 471-491 (2003)

Hutchens, R.M.: Delayed payment contracts and a firm's propensity to hire older workers. J. Lab. Econ. 4, 439-457 (1986)

Hutchens, R.M.: Do job opportunities decline with age? Ind. Labor Relat. Rev. 42, 89-99 (1988)

Hutchens, R.M.: Restricted job opportunities and the older worker. In: Mitchell, O. (ed.) As the Workforce Ages, pp. 81-102. ILR Press, Ithaca (1993)

Hutchens, R.M.: 2001. "Employer Surveys, Employer Policies, and Future Demand for Older Workers," Working Paper, Cornell University

Idson, T.L., Valetta, R.G.: Seniority, sectoral decline, and employee retention: an analysis of layoff unemployment spells. J. Lab. Econ. 14, 654-676 (1996)

Ilmakunnas, P., Ilmakunnas, S.: Diversity at the workplace: whom does it benefit? De Economist. 159, 223-255 (2011)

Jirjahn, U.: The introduction of works councils in German establishments - rent seeking or rent protection? Brit. J. Ind. Relat. 47, 521-545 (2009)

Jirjahn, U.: 2014. "Works Councils and Collective Bargaining in Germany: A Simple but Crucial Theoretical Extension," Research Papers in Economics No. 13/14, University of Trier

Koller, B., Gruber, H.: Ältere Arbeitnehmer im Betrieb und als Stellenbewerber aus der Sicht der Personalverantwortlichen. Mitteilungen Arbeitsmarkt- Berufsforschung. 34, 479-505 (2001)

Kotlikoff, L., Gokhale, J.: Estimating a firm's age-productivity profile using the present value of a workers earnings. Quart. J. Econ. 107, 1215-1242 (1992)

Kriechel, B., Muehlemann, S., Pfeifer, H., Schütte, M.: Works councils, collective bargaining, and apprenticeship training - evidence from German firms. Ind. Relat. 53, 199-222 (2014)

Lahey, J.: State age protection laws and the age discrimination in employment act. J. Law Econ. 51, 433-460 (2008)

Lallemand, T., Rycx, F.: Are older workers harmful for productivity? De Economist. 157, 273-292 (2009)

Lazear, E.P.: Why is there mandatory retirement? J. Polit. Economy. 87, 1261-1284 (1979)

Lazear, E.P.: Agency, earnings profiles, productivity, and hours restrictions. Am. Econ. Rev. 71, 6-20 (1981)

Lazear, E.P.: Pensions and deferred benefits as strategic compensation. Ind. Relat. 29, 263-280 (1990)

Lazear, E.P., Moore, J.: Incentive, productivity and labor contracts. Quart. J. Econ. 95, 703-736 (1984)

Liu, J.T., Tsu, M.G., Wang, P.: Workforce composition and firm productivity: evidence from Taiwan. Econ. Inquiry. 84, 1032-1047 (2009)

Macpherson, D.A., Prasad, K., Salmon, T.C.: Deferred compensation vs. efficiency wages: an experimental test of effort provision and self-selection. J. Econ. Behav. Organ. 102, 90-107 (2014)

Mahlberg, B., Freund, I., Cuserma, J.S., Prskawetz, A.: Ageing, productivity and wages in Austria. Lab. Econ. 22, 5-15 (2012)

Manger, C.: 2013. "Endogenous Age Discrimination," Journal of Population Economics, Forthcoming

Mazerolle, M.J., Singh, G.: Older Workers' Adjustments to Plant Closures. Relations Industrielles - Ind. Relat. 54, 313-336 (1999)
Medoff, J.L., Abraham, K.G.: Experience, performance and earnings. Quart. J. Econ. 95, 703-736 (1980)

Neumark, D.: 2010. "Detecting Discrimination with Audit and Correspondence Studies", IZA Discussion Paper No. 5263

OECD: Ageing and employment policies_-Japan. OECD, Paris (2004)

OECD: Ageing and employment policies-live longer, work longer. OECD, Paris (2006)

OECD: Employment outlook. OECD, Paris (2010)

Oi, W.: Labor as a quasi-fixed factor. J. Polit. Economy. 70, 538-555 (1963)

Petersen, M.A.: Pension reversions and worker-stockholder wealth transfers. Quart. J. Econ. 107, 1033-1056 (1992)

Pfeifer, C.: Adjustments of wage-tenure profiles with respect to entry age. J. Bus. Econ. 83, 171-191 (2013)

Pfeifer, C., Wagner, J.: Is innovative firm behavior correlated with age and gender composition of the workforce? Evidence from a new type of data for German enterprises. J. Labour Mark. Res. 47, 223-231 (2014a)

Pfeifer, C., Wagner, J.: Age and gender composition of the workforce, productivity and profits: evidence from a new type of data for German enterprises. Contemp. Econo. 8, 25-49 (2014b)

Rabe, B.: The role of firm pensions for job change in Germany. Schmollers Jahrbuch. 125, 63-74 (2005)

Reynolds, J., Wenger, J.B.: Prelude to a RIF: older workers, part-time hours and unemployment. J. Aging Soc. Policy. 22, 99-126 (2010)

Riach, P.A., Rich, J.: Field experiments of discrimination in the market place. Econ. J. 112, 480-458 (2002)

Riach, P.A., Rich, J.: 2006. "An Experimental Investigation of Age Discrimination in the French Labour Market," IZA Discussion Papers 2522

Riach, P.A., Rich, J.: 2007. "An Experimental Investigation of Age Discrimination in the Spanish Labour Market," IZA Discussion Papers 2654

Riach, P.A., Rich, J.: 2010. "An Experimental Investigation of Age Discrimnation in the English Labor Market," Annals d'Economie et de Statistique 99-100: 169-186

Roberts, J., Rice, N., Jones, A.M.: Early retirement among men in Britain and Germany: how important is health? Geneva P. 35, 644-667 (2010)

Robinson, A., Zhang, H.: Employee share ownership: safeguarding investments in human capital. Brit. J. Ind. Relat. 43, 469-488 (2005)

Schleife, K.: Computer use and the employment status of older workers: an analysis based on individual data. Labour. 20, 325-348 (2006)

Schnabel, C., Wagner, J.: Betriebliche Altersversorgung: Verbreitung, Bestimmungsgründe und Auswirkungen auf die Personalfluktuation. In: Frick, B., Neubäumer, R., Sesselmeier, W. (eds.) Die Anreizwirkungen betrieblicher Zusatzleistungen, pp. 69-93. Rainer Hampp Verlag, München und Mering (1999)

Schnabel, C., Wagner, J.: A note on pensions and firm performance: first evidence from German micro data. J. Lab. Res. 22, 207-211 (2001)

Schnalzenberger, M., Schneeweis, N., Winter-Ebmer, R., Zweimueller, M.: Job quality and employment of older people in Europe. Labour. 28, 141-162 (2014)

Schneider, L.: Mit 55 zum alten Eisen? Eine Analyse des Alterseinflusses auf die Produktivität anhand des LIAB. J. Labour Mark. Res. 40, 77-97 (2007)

Scott, F.M., Berger, M., Garen, J.: Do health insurance and pension costs reduce the job opportunities of older workers? Ind. Labor Relat. Rev. 48, 775-791 (1995)

Skirbekk, V.: Age and individual productivity: a literature survey. In: " in Feichtinger, G. (ed.) Vienna Yearbook of Population Research. Verlag der Österreichen Akademie der Wissenschaften, Vienna (2004) 
Skirbekk, V.: Age and productivity capacity: descriptions, causes and policy options. Ageing Horizons. 8, 4-12 (2008)

Smith, S.C.: On the economic rationale for codetermination law. J. Econ. Behav. Organ. 12, 261-281 (1991)

Soskice, D.: Reconciling markets and institutions: the german apprenticeship system. In: Lynch, L. (ed.) Training and the Private Sector: International Comparisons, pp. 24-60. Cambridge University Press, Cambridge (1994)

Tipper, A.: (2012) "Labour Productivity, Real Wages, and Workforce Age Structure," Working Paper, Statistics New Zealand, Wellington, June 28

Valetta, R.G.: Declining job security. J. Lab. Econ. 17, S170-S197 (1999)

van Ours, J.: Will you still need me: when I'm 64? De Economist. 157, 441-460 (2009)

Wanger, S.: 2009. "Altersteilzeit: Beliebt, aber nicht zukunftsgerecht," IAB Kurzbericht 08/2009

Zwick, T.: Seniority wages and establishment characteristics. Lab. Econ. 18, 853-861 (2011)

Zwick, T.: Earnings losses after non-employment increase with age. Schmalenbachs Bus. Rev. 64, 2-19 (2012a)

Zwick, T.: Consequences of seniority wages on the employment structure. Ind. Labor Relat. Rev. 65, 108-125 (2012b)

Zwick, T.: Seniority wages and employee participation. Adv. Econ. Anal. Participatory Labor-Manag. Firm. 13, 343-360 (2012c)
John S. Heywood is Distinguished Professor of Economics and Director of the Graduate Program in Human Resources and Labor Relations at the University of Wisconsin-Milwaukee. An expert in the economics of personnel, he has held appointments in the UK, Germany, Hong Kong and Australia. His research examines performance pay, earnings discrimination, the labor market for older workers, the determinants and consequences of family friendly firm practices, public sector labor markets and the economics of trade unions. He has consulted for national governments, the World Bank, major corporations and trade unions. The author of more than 150 articles, his research appears in leading outlets including the Journal of Political Economy, Review of Economics and Statistics, Journal of Labor Economics, Journal of Health Economics and Journal of Public Economics.

Uwe Jirjahn is Professor of Economics at the University of Trier. He researches labor market economics and personnel economics, with special interests in works councils, teamwork, performance pay, migration, older employees, single parents, discrimination, and the labor market consequences of foreign ownership. Among other journals, he has published in British Journal of Industrial Relations, Industrial and Labor Relations Review, Industrial Relations, Journal of Economic Behavior and Organization, Journal of Population Economics, Economics Letters, Labour Economics, Oxford Economic Papers, Oxford Bulletin of Economics and Statistics, Scandinavian Journal of Economics, Social Science Quarterly, and Urban Studies. 